\title{
Heart Is Active Citizenship: Reimagining Civic Education
}

\author{
Seungho Moon', Jenna Mortensen Nelson'1, Yeorim Hwang², Mary Danley³ \\ ${ }^{1}$ Teaching and Learning Program, School of Education, Loyola University Chicago, Chicago, IL, USA \\ ${ }^{2}$ School of Teaching and Curriculum Leadership, College of Education, Oklahoma State University, Stillwater, OK, USA \\ ${ }^{3}$ Margaret White Elementary School, Blythe, CA, USA \\ Email: smoon3@luc.edu
}

How to cite this paper: Moon, S., Nelson, J. M., Hwang, Y., \& Danley, M. (2017). Heart Is Active Citizenship: Reimagining Civic Education. Creative Education, 8, 1673-1681.

https://doi.org/10.4236/ce.2017.810113

Received: July 18, 2017

Accepted: August 13, 2017

Published: August 16, 2017

Copyright (C) 2017 by authors and Scientific Research Publishing Inc. This work is licensed under the Creative Commons Attribution International License (CC BY 4.0).

http://creativecommons.org/licenses/by/4.0/

\begin{abstract}
The ARtS (Aesthetic, Reflexive thoughts, \& Sharing) Initiative is an innovative program for engaging children in reflexive thought about active citizenship in urban communities. This article explicates how children use art to imagine the alternatives in civic education. Using the heart metaphor as active citizenship, the authors illustrate how this organ connects citizens and pumps our desire for a better community through our veins, thus instigating social change. This article demonstrates the power of imagination to inspire students to conceptualize a more just society.
\end{abstract}

\section{Keywords}

Aesthetic Education, Civic Education, Art-Based Inquiry, Urban Education

\section{The Art of Heart}

Educators live in a dichotomous world: theory and experience, teaching and learning, and researcher and practitioner. Maxine Greene proposes the possibility of educators multiplying educational experience by turning to metaphor and releasing the imagination (Greene, 1994). In literature, a metaphor is a word or phrase that denotes an object or idea that it is not literally related to in order to make a comparison. This figure of speech allows words or phrases to characterize something else, like an abstract idea. We regard metaphor as the space and place where educators, policy makers, and students can imagine alternatives in civic education. We examine the ways in which children use metaphor to reflect their lived experience through an aesthetic-inspired afterschool program-The ARtS (Aesthetic, Reflexive thoughts, \& Sharing) Initiative. This universitycommunity-school partnership was designed to advance students' understanding of active citizenship, multiple perspectives, and social equity through the in- 
corporation of artistic expression through art. Educators in civic education and art have endeavored to create innovative programs and theories and this project participates in on-going efforts in the field. By imagining different realities in their urban communities, the ARtS children, comprised of 4th - 6th graders in an urban context, visualized and verbalized abstract notions of active citizenship and community using metaphors ${ }^{1}$.

Imagination makes metaphors possible in the creation of the ARtS children's depiction of their communities. Children imagined and represented their understanding of active citizenship and community through the use of metaphor format: Active citizenship or community is [blank]. Children filled in the blank metaphorically using poetry, clay art, and dancing. Art itself already encompasses metaphorical expressions, and Teaching Artists (TA) put in effort to embody children's imagination through artistic expressions. Children were encouraged to release their imagination-imagination that makes the familiar unfamiliar and bonds unrelated things together. Through imagination, children looked at alternative, other realities, which allowed them to engage in dynamic civics education inquiry (Greene, 1995).

In representing their understanding of active citizenship, the ARtS children applied vivid metaphors and unexpected, imaginative realities. These metaphors include summer school, an awesome party, a tree and seeds, a flower, and a nurse. Notably, the heart was the most outstanding metaphor circulated in children's imagination. As the heart is the center of our body, so is the heart the center of illustrating the notions of active citizenship and community. The heart, the center of our body and soul, enables our body and moves our spirit. The oxygen of heart is true joy-the joy of imagining alternatives that the community has not thought about before, or at least has not explicitly articulated. The heart is at the center of our discourse concerning the ways in which children imagine different versions of community while engaged in art and the aesthetic experience. As new oxygen and nutrition are circulated through veins, we ponder about the meaning of living with others and circulate freedom for creating a democratic community with the alternative realities (Greene, 1998). Art and the aesthetic experience provided the ARtS team of children, TAs, classroom teachers, and university professors with the pulsating desire to engage in civic duties by reimaging alternative realities in our communities as active citizens.

\section{The Pulse of Heart}

Medical science informs us that the human heart beats 100,000 times a day. Each minute, the heart pumps 1.5 gallons of blood (Cleveland Clinic, 2016). As this blood pumps through our veins, as does our desire for human connection. The human heart, the beating center of the community, with tremendous energy and effort, connects the souls of its citizens. These souls pump life and vivacity into

${ }^{1}$ This paper is part of a larger study to introduce an aesthetic inspired afterschool program. For further information of this larger study, refer to two published articles (Moon, 2016a; Moon, 2016b). 
the community in a greater way than any one heart ever could. The boundless expanse of the human heart calls for a greater purpose than a vital organ. With each pump, the heart repeatedly calls for communal connections that are united as one. Throughout the ARtS Initiative, the children displayed this sentiment, particularly though interpretive dance.

During the Initiative, children learned and practiced basic dance skills including repetition, level change, and locomotion. Inspired by the communal beating of the human heart, Iva ${ }^{2}$ and Angela created the shape of the heart with the use of fingers and demonstrated their understanding of repetition, through displaying the heart pumping repeatedly in living things (Figure 1).

Iva: Active citizenship was working together because me and Angela work together ... and then I was hoping to help when she didn't know what to do ... so I helped her know the dance moves, and then we both worked it out ... I felt like dance moves is also active citizenship... because you're feeling about someone in the heart...

Dr. Letters: So, you're making a repetition to make a heart, right? To emphasize it...

Iva: Uh Huh ... Yeah, and when we work together our heart beats...

Dr. Letters: It goes faster?

Iva: Yeah, it goes faster like that ... Yeah, and then it blows up and it goes sparkles [laughter]...

As seen in the repetitive motions of Iva and Angela, the rhythm of our hearts runs through us like a graceful dance. The heart moves us to insight change and moves us to connect. Beating like a drum, the heart beating 100,000 times a day carries these visions and makes them a reality that changes lives, not for one, but for many.

Pulsating, the heart yearns for personal connections-connections that warm the soul in a gentle embrace. While preparing a community night that allowed

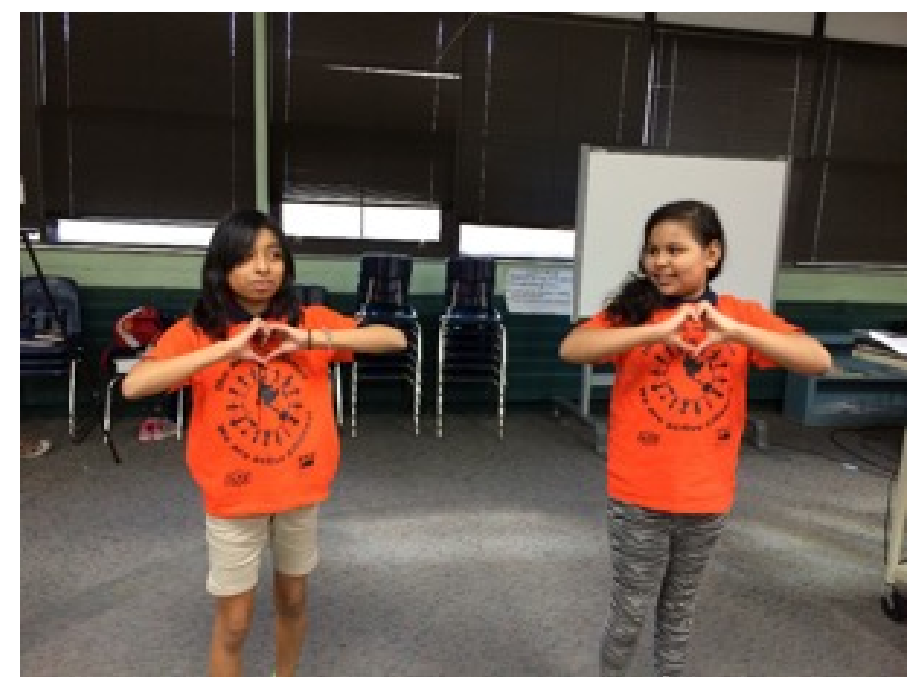

Figure 1. Active citizenship is heart by Iva and Angela.

${ }^{2}$ All the names in this paper are pseudonyms. 
for the ARtS team to share what they learned, the dancer, professors, classroom teachers, and children altogether contributed to choreographing dance moves representing active citizenship. Jennifer and Chase, as a pair, performed their gestures in front of peers, the dancer, and the professor. In front of their peers, the two girls each moved one outstretched hand, and then the other, in front of their bodies. Sweeping their arms forward, they displayed a graceful semi-circular motion. They then crossed their arms in front of their chests, each hand embracing the opposite shoulder. Next, placing both hands at hip level, palms facing forward, to the sides of their bodies with arms open, they gently swung their arms up towards the ceiling and swooped them back down in a diving motion until they reach their starting positions. Delicately embracing and folding each hand over the opposite shoulder, the girls, ultimately, beautifully displayed their understanding of active citizenship through love-the need for communal embrace. As they repeated these motions, it appeared as if their movements pulsated like the heart. Beating, pulsating, pounding, the heart carries the human need for love through our veins.

As blood moves by heartbeat so do children's thoughts about community and love. Commenting on Jennifer and Chase's dancing, other children interpreted and added comments about Jennifer and Chase's movement. Stacy, a fourth grader, mentioned how folding hands to the partner's shoulder was an attempt to "communicate the love" to each other. Tavis, another fourth grader, mimicked the motion of Chase and Jessica by crossing his arms in front of his chest, each hand embracing the opposite shoulder. While copying this motion, Tavis was curious about why people use this move to represent love. Tracy, a fifth grader, proposed that this move is used because "your heart's right here so it's like crossing your heart". Tavis then offered the following insight to connect Tracy's interpretation with his own idea: "crossing [your] heart is like you have friends and you carry them in your heart". After this elaboration of possible moves to represent active citizenship, Arias, the dance instructor, led the children to make the corresponding movements. The students moved one outstretched hand and then the other in front of their bodies, sweeping forward and to their sides in a graceful semi-circle. Imagining heart in the community, the ARtS children crossed their arms in front of their chests, each hand embracing the opposite shoulder. The united pulsating of our hearts, like the unified movements of the students, draws humans together in a warm, comforting embrace that protects and consoles the soul. With each pulsating heartbeat, we hold our companions close to us. In our soul, the epicenter of our body is where we cherish our human connections, keeping our loved ones safe in our embrace.

\section{The Circuit of Heart}

Each hour, our heart circulates 90 gallons of blood (Cleveland Clinic, 2016). And it our lifetime, the heart pumps an average of 1 million barrels of blood, the equivalent of three super tanker trucks (Mercola, 2016) With all this power, the 
area of the heart has no boundaries, has no limits. Its unconditional compassion knows no restrictions, knows no prejudices, knows no predispositions. Much like the heart, active citizenship has no margins-it can connect time, space, class, ethnicity/race. It breathes life into a community that may otherwise be grasping for air. It thrusts opportunity for new possibilities, for change. Heart as the agent for sustaining change keeps our body healthy, flowing the liquid of life perpetually. Durkheim, a sociologist, uses a heart-circuit metaphor in explaining how individual heart is socially connected. "[I]f all hearts beat in unison, this is not as a consequence of a spontaneous, pre-established harmony; it is because one and the same force is propelling them in the same direction" (Durkheim, 1982: p. 56). The collective emotion of citizens is a "product of shared existence, of actions and reactions called into play between the consciousness of individuals" (p. 56). Human's veins are connected to the heart and are socially interconnected like a circuit, creating new realities that propel all citizens' need for a more just, equitable society.

The ARtS children shared also their ideas about "being connected" through the use of a heart metaphor. Chalet, a sixth grader, decorated her pinch pot cup with a heart to symbolize her desire to connect to others. She said, "People want you to see things and feel about the community and citizenship. And the heart [in this pinch pot] is for like ... all you have to do is just to listen and express how you feel from the heart and it feels like connected". All veins are connected through the heart. Likewise, the heart, as active citizenship, reveals the desire to connect to others, to find companionship and safety within the warmth of other hearts in the community. The heart is at the center of this compassion as it is connected to the lived experiences of all citizens, circulating towards a common goal of interconnection.

At the center of the body, the epicenter, the soul, the heart thrusts life into all living things. Circulating vital elements throughout the body, young and old, the heart holds our life in its hands. These lives are harmoniously connected through the lived human experience, allowing us to empathize and link to the experiences of others. This outlook was displayed during the ARtS Initiative by Alicia, a fifth grader, through her poetry and collage (Figure 2). She listed several images of active citizenship with the use of metaphors, including a vitamin, a sweet cupcake, and a bed sheet:

Active citizenship is nutrition/giving the community a vitamin daily/Being able to keep it healthy and clean like a nurse ... Active citizenship is a dog/A friend for the community/It will allow you to ask it for love with a friendly trick/It is a random act but as sweet as a cupcake/adding new frosting for each batch ... Active citizenship is a bed being made everyday/We change sheets everyday to keep us warm and cozy/To always keep us warm at night (Alicia).

Human lives are connected through the veins of the heart, like a circuit, causing us all to crave the sustenance of human relationship and comfort. Like Alicia's 


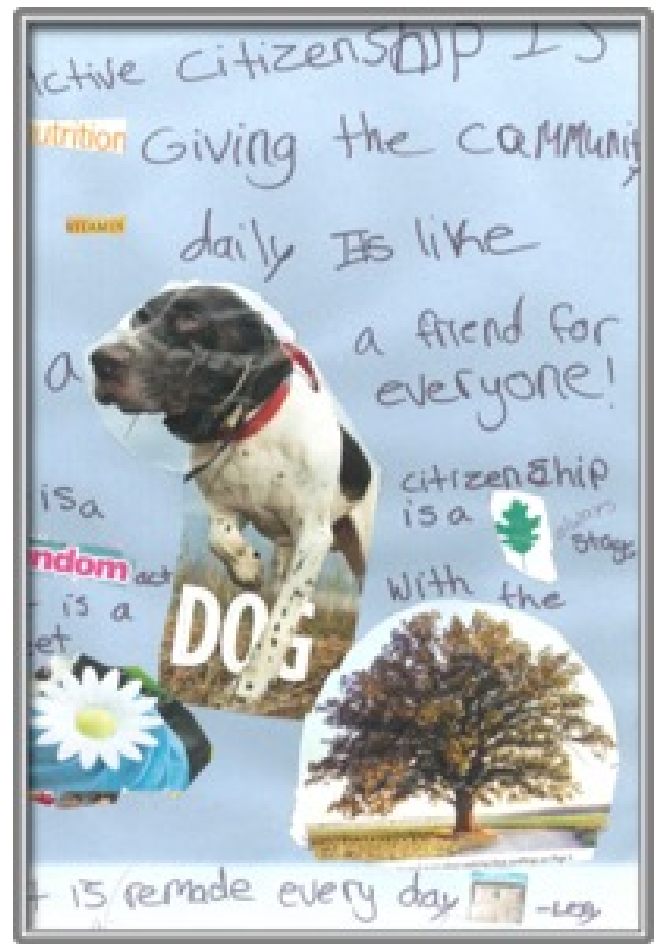

Figure 2. Alicia's poetry on active citizenship.

poem, active citizenship nourishes this human need. Our connected hearts in the community is like offering a daily vitamin for the community through love. Shared hearts is similar to living with a service dog, asking for constant love for humans and communities. Humans are also emotionally rejuvenated through this circuit connection. Rejuvenation through active citizenship, as noted by Alicia, is like, "adding new frosting for each batch" of cupcakes or making a bed every day "to keep us warm and cozy. To always keep us warm at night". The warmth experienced through human interconnectedness allows individuals to feel protected, comforted, and rejuvenated through their relations to others, breathing life into many.

Active citizenship, expressed through art and civic education, circulates through the hearts and minds of the community, classroom teachers, policy makers, and students. The connections developed foster an interrelatedness that crosses age, gender, and ethnicity/race. The heart's capacity to relate and connect all individuals grips the core of the soul. Kahlo's (1939) "Las Dos Fridas" further highlights the interconnectedness of human hearts. In this image, Kahlo depicts two women, with exposed hearts, connected by the veins of their souls. The connected veins circulate life through both women, creating a shared existence. The image of fire surrounding the open hearts of the women also reveals a yearning for connection, a desire to feel a relation to another soul. Joining together as one, through civic engagement, citizens can create a whole heart prepared to engage in social change. In hopeless times, when hardship seems the greatest, the heartbeat of the community tugs together the lives of its citizens, inspiring all to labor for social change, for a stronger future for all. 


\section{The Heart of ARtS}

Metaphors open a door for expressing creative ideas without constraint. In-between space in existing binaries is imagined and created, which can enrich student's conceptions of civic engagement. Metaphors not only connect theory and experience, but also multiply interpretations of reality (Greene, 1994). Propelling life throughout the body, the heart takes the vital elements we cannot see and makes them the fuel for our existence. Much like the heart, active citizenship pieces together citizen's visions for the community and turns these images into reality. The power of art and art of power reside in opening imaginative space and place. The ARtS initiative, as both the space and place, values the learning process as well as considers affirmative learning experience through an open, supportive partnership. The practice of metaphors supported by poetry, movement, and dance allowed the ARtS children to build the consciousness that encouraged them to engage in an on-going commitment to the community. When children are exposed to a different way of thinking, a new awakening occurs that is connected to revisiting their existing values and accepting different perspectives and lives.

This paper is significant in that the art of metaphors offered children a forum to illustrate their personal experiences and mitigate the threats that they are exposed to in the community (Rhodes \& Schechter, 2014). Their stories and metaphors can represent acts of power and can inspire civic-minded engagement as the heart circulates blood through the veins in the body and clears up the body (Greene, Burke, \& McKenna, 2013). To better engage children in civic responsibilities, educators should consider shifting away from "old civics" practices to the "new civics". Building off the "old civics", the "new civics" focuses on students learning civic knowledge as well as "the skills and dispositions necessary to engage civically"; this knowledge includes, "civic knowledge, civic skills, and civic dispositions" (Education Commission of the States, 2013: p. 2). Moving beyond the passive learning of citizenship, students must play an active and dynamic role in conceptualizing and enacting civic duties. Such is seen in the ARtS Initiative as students with a warm-hearted mindset, without already-restricted borders or limitations, produced a sense of compassion and passion in the community. The art of "heart" exists in this affective domain of civic education, like Iva's image that the heart opens the space for participation in the urgent issues in the community. This sentiment notably exposes a safety issue in their community. Active citizens are "personally responsible, participatory, and justice oriented" (Westheimer \& Kahne, 2004: p. 237), allowing for them to gain an insight into communal change and address social justice issues, like safety. A heart metaphor opens space to the construction of love that permeates through students imagining their active roles in the community. The affective side of civic education increases children's civic engagement while providing platforms for intellectual, emotional, and social development (Greene, Burke, \& McKenna, 2013; Neuman, 2010).

As a healthy heart is the core of healthy body/soul/spirit, the ARtS initiative 
sought the possibility of promoting children's appreciation of art and their aesthetic experience by creating a healthier community. This project provides both theoretical and practical implications for art educators and teacher educators as it encourages teachers to imagine different approaches to art education that can promote social equity through emphasizing the aesthetic experience and encouraging students to consider multiple perspectives. The heart metaphor that children created in this study exemplifies this value as it shows how such approaches lead students to a compassionate engagement with the community through sharing and supporting diverse thoughts and perspectives. Children shared their stories through diverse modes of metaphors that spanned across time and space. By doing so, the notions of active citizenship and community went beyond the civic responsibilities, rights or government that appear in conventional social studies curriculum. This reality has the potential to enrich civics education and ought to be considered by classroom teachers and policy makers. Children's artistic creativity and aesthetic experience, followed by a shared reflection on their artwork, became the tool to reveal the value of the community and to imagine a safer, more just society. The heart of the ARtS, thus, resides in this possibility to circulate oxygen desperately needed in sustaining a healthy, just community.

\section{Acknowledgements}

The ARtS Initiative was supported by the Oklahoma Arts Council-Major Grants (\#2493-4033) and Oklahoma State University (ED-13-OT-045).

\section{References}

Cleveland Clinic (2016). Amazing Facts about Your Heart. https://health.clevelandclinic.org/2016/08/22-amazing-facts-about-your-heart-infograp $\underline{\text { hic/ }}$

Durkheim, E. (1982). The Rules of Sociological Method. New York: The Free Press. https://doi.org/10.1007/978-1-349-16939-9

Education Commission of the States (2013). The New Civics: Civic learning Is Not Flat Learning. Educational Reform, 14, 1-8.

Greene, M. (1994). Epistemology and Educational Research: The Influence of Recent Approaches to Knowledge. Review of Research in Education, 20, 423-464. https://doi.org/10.2307/1167390

Greene, M. (1995). Releasing the Imagination: Essay on Education, the Arts, and Social Change. San Francisco, CA: Jossey-Bass.

Greene, M. (1998). The Dialectic of Freedom. New York: Teachers College Press.

Greene, S., Burke, K., \& McKenna, M. (2013). Forms of Voice: Exploring the Empowerment of Youth at the Intersection of Art and Action. Urban Review, 45, 311-334. https://doi.org/10.1007/s11256-012-0228-Z

Kahlo, F. (1939). Las Dos Fridas.

Mercola (2016). Fascinating Facts about the Human Heart. http://www.mercola.com/infographics/human-heart-facts.htm

Moon, S. (2016a). “Active Citizenship Is an Awesome Party!” Creating In-Between Spaces 
for the School-Community-University Partnership. Teaching Artist Journal, 14, 145153. https://doi.org/10.1080/15411796.2016.1209353

Moon, S. (2016b). The ARtS Community without Community: Imagining Aesthetic Curriculum for Active Citizenship. Sage Open, 6, 1-11. https://doi.org/10.1177/2158244016664772

Neuman, S. B. (2010). Empowered-After School. Educational Leadership, 67, 30-36.

Rhodes, A. M., \& Schechter, R. (2014). Fostering Resilience among Youth in Inner City Community Arts Centers: The Case of the Artists Collective. Education and Urban Society, 46, 826-848. https://doi.org/10.1177/0013124512469816

Westheimer, J., \& Kahne, J. (2004). What Kind of Citizen? The Politics of Educating for Democracy. American Educational Research Journal, 41, 237-269.

https://doi.org/10.3102/00028312041002237

Submit or recommend next manuscript to SCIRP and we will provide best service for you:

Accepting pre-submission inquiries through Email, Facebook, LinkedIn, Twitter, etc. A wide selection of journals (inclusive of 9 subjects, more than 200 journals)

Providing 24-hour high-quality service

User-friendly online submission system

Fair and swift peer-review system

Efficient typesetting and proofreading procedure

Display of the result of downloads and visits, as well as the number of cited articles Maximum dissemination of your research work

Submit your manuscript at: http://papersubmission.scirp.org/

Or contact ce@scirp.org 